- складність деякого програмного забезпечення для потокового вивчення;

- не вистачає викладачів, які володіють комплексно професійним програмним забезпеченням;

- відсутність методичного матеріалу;

- організація інформаційно-освітньої бази даних;

- моделювання засобів навчального середовища.

Резюмуючи, варто зазначити, що впровадження геоінформаційних технологій в освіту відкриває принципово нові можливості для управління навчальнопізнавальною діяльністю і їі інтенсифікації, вони дозволяють значно збільшити обсяг інформації, істотно розширюють межі реальної дослідницької діяльності майбутніх інженерів. Незважаючи на недоліки та переваги в навчальному процесі інженерних спеціальностей, питанню використання геоінформаційних технологій мають присвячуватися круглі столи, тренінги, семінари, конференції задля ефективного розв'язання окресленої проблеми.

\title{
Література
}

1. Ахметова Д. 3. Дистанционное обучение: от идеи до реализации : [монография] / Д. З. Ахметова; Ин-т экономики, управления и права. Казань: Познание, 2009. - 176 с. 2. Геоинформатика: [учебник для студ. высших учебн. заведений, обучающихся по специальностям 012500 «География», 013100 «Природопользование», 013600 «Геоэкология», 351400 «Прикладная информатика (по областям)»]/ Е. Г. Капралов, А. В. Кошкарев, В. С. Тикунов и др.; под ред. проф. В. С. Тикунова; Московский государственный университет имени М. В. Ломоносова. М. : Академия, 2005. - 480 [8] с. - (Классический университетский учебник). 3. Жалдак М. І. Проблеми інформатизації навчального процесу в середніх і вищих навчальних закладах / М. І. Жалдак // Комп’ютер в школі та сім’ї. - 2013. - № 3. C. 8-15. 4. Konečný M. Geografické informační systémy / M. Konečný, K. Rais; Univerzita J. E. Purkyně v Brně. Př́rodovědecká fakulta. -[Brno] : Univerzita J. E. Purkyně v Brně, 1985. - 195, [1] s. - (Folia Facultatis Scientiarum Naturalium Universitatis Purkynianae Brunensis. Geographia. - 21). 5. Медведська Л. Дмитро Табачник: «Ми відродили й відновили систему підтримки обдарованої молоді» [Електронний ресурс] /Людмила Медведська. - [16.04.2012]. - Режим доступу :http://www.mon.gov.ua/ ua/news /archive-news /89/dmitro-tabachnik-mividrodili-vidnovili-sistemu- pidtrimki-obdarovanoji-molodi/ 6. Про основні засади розвитку інформаційного суспільства в Україні на 2007-2015 роки : Закон України від 09.01.2007 № 537-V / Верховна Рада України. Стаття 102. // Відомості Верховної Ради України. - 23.03.2007. - № 12. - С. 511.7. Роберт И. В. Современные информационные технологии в образовании: дидактические проблемы; перспективы использования / И. В. Роберт. - М. : ИИО РАО, 2010. - 140 с. 8. Холошин І. В. Педагогічна геоінформатика. Ч. 1. Дистанційне зондування Землі: [навч. посібн.] / I. В. Холошин. - Кривий Ріг : Видавець ФО П Чернявський Д. О., 2013. - 224 с.

\section{МОДЕРНІЗАЦІЯ ВИЩОЇ ШКОЛИ УКРАЇНИ В СУЧАСНИХ УМОВАХ ЗАДЛЯ ФОРМУВАННЯ ПРОФЕСІЙНОГО МОВЛЕННЯ ФАХІВЦЯ НЕФІЛОЛОГІЧНОГО ПРОФІЛЮ}

Дроздова I. П. Модернізація вищої школи України в сучасних умовах задля формування професійного мовлення фахівця нефілологічного профілю. 
У статті розглядається проблема модернізації вищої школи України задля формування професійного мовлення фахівця нефілологічного профілю в сучасних умовах розвитку українського суспільства. Автор виокремлює поняття «мовно-професійне виховання», що пов'язане з формуванням професійно досконалої особистості.

Ключові слова:модернізація освіти, професійне мовлення, комплекс компетенцій, мовно-професійне виховання, формування особистості.

Дроздова И. П. Модернизация высшей школы Украины в современных условиях с целью формирования профессиональной речи специалиста нефилологического профиля.

В статье рассматривается проблема модернизации высшей школы Украины с целью формирования профессиональной речи будущих специалистов нефилологического профиля в современных условиях развития украинского общества. Автор выделяет понятие «языковое профессиональное воспитание», связанное с формированием профессионально совершенной личности.

Ключевые слова:модернизация образования, профессиональная речь, комплекс компетенций, языковое профессиональное воспитание, формирование личности.

Drozdova I. P. Modernisation of Higher School of Ukraine in modern conditions to form a professional speech specialist philological profile.

This article takes into consideration the problem of professional formation of the nonphilological specialists in conditions of the High School modernization in modern conditions of development of Ukrainian society. Author distinguishes the concept of «linguistic professional education» related to the formation of professionally perfect person.

Key words:education modernization, professional speaking, competence complex, linguistic professional education, personality formation.

Загальноєвропейський Болонський процес ставить перед вищою школою України нові проблеми, пов'язані з модернізацією вищої освіти в сучасних умовах, що потребує створення перспективної концепції іiї розвитку. Виходячи за межі традиційних підходів, майбутнє вбачається заінноваційним шляхом, який дістав підтримку в багатьох розвинених країнах світу.

Інноваційний шлях України можна забезпечити, сформувавши покоління професіоналів, які мислять по-новому. У сучасних умовах проектування власної кар'єри, вибір життєвих стратегій, моделей саморозвитку й самоактуалізації особистості (3-поміж яких першочерговими $\epsilon$ національна самоідентифікація, розвиток духовності, інтелекту, волі, мовне і мовленнєве вдосконалення, формування професійних якостей тощо) стає більш усталеним, усвідомлюваним і незалежним від зовнішніх обставин. Досягнення людиною рівня самоактуалізації $\epsilon$ необхідною умовою соціального прогресу. Це насамперед стосується реформування освіти, що буде ефективною лише за умови забезпечення самоактуалізації особистості.

Модернізація освіти стосується всіх освітніх галузей і напрямків діяльності, наразі й такого напрямку, як українська мова задля формування професійного мовлення фахівців різних галузей виробництва згідно 3 вимогами суспільства i потребами ринку праці. Така модернізація освітньої діяльності в Україні відбувається в контексті європейських вимог задля входження до освітнього та наукового простору Європи згідно з принципами Болонської декларації [1].

Останнім часом у зв'язку з приєднанням України до Болонського процесу погляд на педагога, його функції й педагогічну техніку як елемент педагогічної майстерності в багатьох ВНЗ України поступово починає змінюватися. 
Завдання підвищення ефективності навчального процесу, якості підготовки фахівців не можуть бути розв'язані без підвищення якості викладання, що безпосередньо пов'язано зі зростанням рівня педагогічної майстерності викладача, без корекції навчального процесу і використання педагогічних інновацій. Це пов'язане, по-перше, з подоланням суперечностей між навчальними програмами університетів і системою викладання в них навчальних дисциплін, i, по-друге, з реальними запитами ринкової економіки і суттєвими вимогами до компетентностей сучасних фахівців.

Підготовка фахівців передбачає не лише формування професійних знань, умінь i навичок, що необхідні в практичній діяльності педагога, а й виховання всебічно розвинутої особистості, розвиток іiі пізнавальних потреб та інтелектуальних здібностей, інтересів та мотивів, духовності, менталітету, формування сучасного світогляду тощо [2; 3].

Щоб змінити процес навчання української мови у стилі стратегії сучасної модернізації освіти з урахуванням європейських вимог, варто насамперед визначити, що означає для методики навчання української мови кредитно-модульна система організації навчання,яка буде реалізована у процесі здійснення модернізації освіти України на основі 3-х підходів: комунікативно-діяльнісного, комунікативнокогнітивного і професійно орієнтованого.

Ця система є моделлю такої організації навчального процесу, що грунтується на поєднанні модульних технологій навчання та залікових освітніх одиниць (залікових кредитів) [4, с. 219].

У якості проектованої мети процесу навчання у вищій школі ми обрали формування професійної українськомовної компетентності фахівця нефілологічного профілю. Вимагається розширення функцій процесу навчання задля максимальної реалізації поставлених завдань. Щоб структура процесу була адекватною структурі «готовності», необхідно його членування на етапи, цілі, засоби яких добираються відповідно до різних станів «готовності» як прогностичними цілями етапів.

Основний напрям дослідження визначив і постановку його завдання: вивчити властивості процесу навчання української мови студентів нефілологічного профілю як цілісного явища, за наявності яких він забезпечує підготовку фахівця відповідно до потреб суспільства й ринку праці. Воно зумовлено необхідністю підвищити рівень теоретичного опису процесу навчання у ВНЗ.

У розв'язанні цього завдання ми спиралися на теорію цілісного процесу формування всебічно й гармонійно розвинутої особистості, яку розробляли А. Алексюк, 3. Бакум, А. Богуш, О. Горошкіна, Н. Голуб, І. Зязюн, І. Журавльов, I. Лернер, Г. Сагач, Л. Паламар, М. Пентилюк, О. Семеног, Т. Симоненко й інші українські та закордонні науковці. На цій підставі під цілісним педагогічним процесом ми розуміємо такий процес, функціонування якого забезпечує формування не тільки окремих компонентів особистості (знань, умінь), але й особистості загалом.

У дослідженнях Л. Барановської, Г. Бондаренко, С. Вдовцової, І. Довженко, Н. Костриці, М. Криськів, Л. Романової, Л. Стасів, Н. Тоцької розглядається формування професійного функційного мовлення як важливого напряму професійної підготовки фахівців у вищій школі. Праці цього напряму зробили істотний внесок у розв'язання питання щодо проведення професійної спрямованості змісту навчання мови, зокрема й української, відповідно до вимог сучасного виробництва і ринку праці.

Однак взаємозв'язок професійної підготовки і розвитку професійного мовлення, вимог суспільства до фахівця і працівника певної професії до цього часу вивчений недостатньо. Актуальним $є$ дослідження проблем, пов'язаних із розвитком 
особистості професіонала, наразі і становлення мовленнєвих знань, умінь і навичок за фахом, що відбувається як у період професійної підготовки, так і після завершення навчання - у процесі роботи за фахом.

Метою статті є вивчення проблем модернізації вищої школи України задля формування професійного мовлення фахівця нефілологічного профілюв сучасних умовах розвитку українського суспільства.

Умови навчання і «заданий» результат навчання визначаються Державним стандартом. На дані стандарту зорієнтовано програми з української мови для вищих нефілологічних навчальних закладів, що останнім часом обмежуються ОКХ (освітньо-кваліфікаційна характеристика спеціальності (напряму підготовки фахівців), у ній подаються вимоги до підготовки фахівців з української мови) та ОПП (освітньо-професійна програма спеціальності, у якій пропонується зміст тем 3 мови для вивчення студентами).

Ці документи визначають кількість годин і обсяг дисципліни мовного напрямку («Ділова українська мова», «Українська мова (професійного спілкування)», «Українська мова (за професійним спрямуванням)» на нефілологічних факультетах ВНЗ. За цими документами розробляються навчальні й робочі програми за факультетами. Якщо таких документів, як ОКХ та ОПП, за факультетськими напрямами навчання не передбачено, то вони дублюються за суміжними спеціальностями.

Задля розв’язання складних завдань модернізації освіти необхідна цілісна система гуманітарно-освітньої й культурно-виховної діяльності. У межах блоку культурологічних дисциплін («Українська і зарубіжна культура», «Етика», «Естетика», «Культурологія», «Ділова українська мова», «Українська мова (за професійним спрямуванням)», «Методика викладання у вищій школі» тощо) як комплексу базових, альтернативних і факультативних курсів ефективним $є$ використання особливих методів навчальної роботи, що синтезують як традиційні, так й інноваційні освітні стратегії із новими інформаційними технологіями, що стосуються всіх галузей вищої освіти. Причому мета комунікації зумовлює необхідність вибору мовних засобів.

Проблема естетичного виховання студентів $є$ актуальною на нинішньому етапі розвитку освіти, оскільки розуміння естетичної функції мови - важлива умова формування професійної мовленнєвої компетенції студентів. Студенти отримують знання про мову, але не знають іiі виразних можливостей i особливостей. В. Русанівський зазначав, що на заняттях з мови органічно поєднуються мова як засіб пізнання, мова як засіб комунікації, мова як засіб апеляції до почуттів, засіб емоційноестетичного виховання [5, с. 98].

На основі аналізу науково-методичних підходів до естетичного виховання (I. Зязюн, В. Лозовой, Г. Сагач) і мовного (3. Бакум, Л. Мацько, Г. Михайловська, Т. Панько, М. Пентилюк, Г. Шелехова), професійного мовлення (Г. Бондаренко, Н. Бородіна, Л. Головата, Л. Златів, Т. Окуневич, Л. Паламар, О. Семеног, Т. Симоненко, Н. Тоцька), ураховуючи наявність виражальних можливостей впливу мови через мовлення, підкреслимо поняття «мовно-професійне виховання».

Це означає цілеспрямоване формування професійно досконалої особистості, здатної свідомо володіти скарбами рідної мови, що дає змогу для розвитку внутрішнього дару слова, гармонійного ділового спілкування, асоціативного фахового мислення, естетичномовних смаків, риторичної довершеності, тобто усього того, що складає вищий рівень розвитку якостей сучасної людини - компетентного фахівця і громадянина.

Отже, соціогуманітарне знання й естетичне виховання дозволяє розв'язати суперечність між людиною і технікою, людиною і природою, забезпечує такий рівень професійної культури, що на етапі проектування мінімізує негативні соціальні 
наслідки інноваційної діяльності, формує здатність до адекватної оцінки й прийняття правильного рішення у критичній діловій ситуації, актуалізує людський, а не тільки технічний зміст негуманітарних або суто інженерних професій.

Соціально-гуманітарний компонент у мисленні й діяльності фахівця виконує свого роду охоронну роль. 3 одного боку, фізична безпека суспільства гарантується соціальною, моральною, професійною компетентністю фахівців. 3 іншого, - знання механізмів функціонування суспільства, специфіки культурної динаміки, уміння спілкуватися, естетичне сприйняття української мови, мовно-естетична вихованість, інтелектуальна гнучкість, психологічна мобільність - усе те, що надає особистості соціально-наукове й гуманітарне знання,- полегшує входження людини в соціум, пошук оптимальних рішень у важких професійних і життєвих обставинах.

Високий рівень професійної культури нині має стати одним із найважливіших критеріїв якості соціально-гуманітарної підготовки фахівця з вищою нефілологічною освітою. Тож засвоєння основ культурологічного знання для формування професійного мовлення засобами української мови повинне орієнтувати освітній процес у ВНЗ нефілологічного профілю на розвиток аксіологічного, естетичного, екологічного і професійного мислення студентів, на культивування ідеї моральної відповідальності індивіда за результати своєї професійної діяльності.

Зазначимо, що сучасна модернізація орієнтується на збереження фундаментальності освіти й одночасне посилення іiі практичної, діяльнісної спрямованості, тому передбачається, що система обов'язкового формування знань, умінь і навичок буде замінена набором компетентностей (комплексом компетенцій, що мають стати в подальшому засобом розвитку студентів. Усвідомлюючи це, можна сказати, що модернізація освіти буде здійснюватися 3 позицій компетентніснодіяльнісного підходу).

Одним із завдань модернізації освіти є визначення ключових компетенцій (компетентностей) на міждисциплінарній і міжпредметній основі. Для вищої школи це буде комунікативно-достатній рівень сформованості всіх компетенцій у базовому варіанті вищого ступеня навчання і профільно-просунутий рівень, безпосередньо пов'язаний із професійним мовленням.

Володіння мовою професійного спілкування - це не тільки сформованість мовної компетенції (норми сучасної української літературної мови, фахова термінологія, специфіка побудови синтаксичних конструкцій, текст та дискурс), але й уміння використовувати ці знання на практиці, доречно поєднувати вербальні та невербальні засоби спілкування відповідно до мети, ситуації спілкування, тобто досконала сформованість професійних комунікативних навичок.

Отже, нагальною є потреба оновлення вищої освіти України й освітньої практики в контексті суспільних змін, глобальних проблем розвитку людства. В умовах соціально-політичних змін у нашій країні це можливо з урахуванням нової ситуації, вимог і потреб українського суспільства, що потребує реформування, оновлення й удосконалення вищої школи.

\section{Література}

1. Богуш А. М. Принципи модернізації вищої освіти / А. М. Богуш // Психологопедагогічні основи гуманізації навчально-виховного процесу в школі та ВНЗ. - Рівне, 2003. - Вип. 4, Ч. 1. - С. 6-9. 2. Вища освіта і Болонський процес :[навч. посіб. для студ. вищ. навч. закл.] / М. Ф. Дмитриченко, Б. І. Хорошун, О. М. Язвінська, В. Д. Дончук. К. : Знання України, 2006. - 440 с. 3. Вища освіта України і Болонський процес: [навч. посібник] / М. Ф. Степко, Я. Я. Болюбаш, В. Д. Шинкарук, В. В. Грубінко, І. І. Бабин; за ред. В. Г. Кременя. - Тернопіль: Навчальна книга. - Богдан, 2004. - 384 с. 4. Педагогічні 
технології : теорія і практика : [навч.-метод. посіб.] / за ред. проф. М. В. Гриньової. Полтава : АCMI, 2006. - 230 с. 5. Русанівський В. М. Мова в нашому житті / В. М. Русанівський. - К. : Наук. думка, 1989. - 112 с.

УДК 378:147

Ганна Захарова

\section{НАУКОВО-ТЕОРЕТИЧНЕ ОБГРУНТУВАННЯ ПОНЯТТЯ «УМІННЯ САМОСТІЙНО-ПІЗНАВАЛЬНОӤ ДІЯЛЬНОСТІ СТУДЕНТІВ»}

Захарова Г. Б. Науково-теоретичне обгрунтування поняття «уміння самостійнопізнавальної діяльності студентів».

У статті здійснено науково-теоретичний аналіз літератури, сучасних дисертаційних працьі 3 проблеми формування умінь пізнавальної діяльності, пізнавальної самостійності та дотичних проблем; зіставлення й порівняння сучасних теоретико-педагогічних здобутків на грунті системно-діяльнісного підходу дозволили надати визначення умінням самостійно-пізнавальної діяльності студента.

Ключові слова:пізнання, діяльність, уміння, самостійно-пізнавальна діяльність, уміння самостійно-пізнавальної діяльності студента.

Захарова А. Б. Научно-теоретическое обоснование понятия «умение самостоятельно-познавательной деятельности студентов».

В статье проведен научно-теоретический анализ литературы, современных диссертационных работ по проблеме формирования умений познавательной деятельности, познавательной самостоятельности и касательных проблем; сопоставление и сравнение современных теоретико-педагогических достижений на основе системно-деятельностного подхода позволили предоставить определение умениям самостоятельно-познавательной деятельности студента.

Ключевые слова:познание, деятельность, умение, самостоятельно-познавательная деятельность, умения самостоятельно-познавательной деятельности студента.

Zakharova G. B. Scientific and theoretical substantiation of the concept of "the ability to self-cognitive activity of students”.

Scientific and theoretical analysis of the literature, modern dissertation research on the formation of the skills of cognitive activities, cognitive independence and related problems has been performed in the article; matching and comparison of modern theoretical and pedagogical achievements on the basis of system-active approach allowed to give definition to the ability to self-cognitive activity of students.

Key words: cognition, activity, skills, self - cognitive activity, ability to self-cognitive activity of a student.

Кожне педагогічне явище й окремий педагогічний феномен потребують ретельного вивчення й аналізу із застосуванням системи різноманітного інструментарію. Загальні орієнтири наукового пошуку налаштовують на активацію резервів системного й діяльнісного підходів у їх єдності та багатоваріантності. Саме тому уважаємо за потрібне здійснити науково-теоретичне обгрунтування феномену умінь самостійнопізнавальної діяльності на грунті системно-діяльнісного підходу, що зберігає своє методологічне значення у психолого-педагогічних (Б. Ананьєв, М. Берман, С. Блауберг, М. Каган, О. Леонтьєв та інші) та філософсько-гуманітарних дослідженнях.

Пізнання - це «супроводжуване усвідомленням істинності розуміння суб'єктом, що пізнає, об'єктивного стану речей, а також результату цього процесу». Підкреслюється, що проблема пізнання тісно пов’язана $з$ проблемою істинності. На відміну від просто думки, пізнання у своїй претензії на істинність може бути обгрунтованим. Структурно організоване пізнання визнають як знання. 